\title{
Determination of Nitrogen Oxides with Rhodamine B by Fluorescence Quenching Method
}

\author{
Yan Pugen, ${ }^{1}$ Qiu Haiou, ${ }^{1}$ Lu Cuili, ${ }^{2}$ and Tang Zhiyong1 \\ ${ }^{1}$ Facuty of Material Sciences and Chemical Engineering, China University of Geosciences, Wuhan 430074, China \\ ${ }^{2}$ Hubei Gedian Humanwell Pharmaceutical Co. LTD, Wuhan 430074, China \\ Correspondence should be addressed to Lu Cuili, xiaol_114@yahoo.cn
}

Received 26 November 2010; Revised 16 January 2011; Accepted 6 February 2011

Academic Editor: Veronica Vaida

Copyright (c) 2011 Yan Pugen et al. This is an open access article distributed under the Creative Commons Attribution License, which permits unrestricted use, distribution, and reproduction in any medium, provided the original work is properly cited.

\begin{abstract}
$\mathrm{NO}_{2}$ can be transformed into nitrite by the absorption of Rhodamine B solution, which will make fluorescence quenching of Rhodamine B in acidic medium. According to this mechanism, a new method for detecting nitrogen oxides in the air is developed by a fluorescence spectrophotometry. The influence of environmental media and interfering substances in the fluorescence intensity of system was studied. Under the optimal experimental conditions, the decrease of fluorescence intensity varies linearly with the concentration of $\mathrm{NO}_{2}^{-}$over the range of $0.009 \sim 0.500 \mu \mathrm{g} / \mathrm{ml}$ with a correlation coefficient of 0.9992 . The method is simple and has a lower limit of detection than the common methods. It can be a referee for the environmental evaluation.
\end{abstract}

\section{Introduction}

Nitrogen oxides are one of the main pollutants as well as the evaluation criteria of the air quality. Nitrogen oxides in the atmosphere have harmful effects on humans mainly through the respiratory system, which may cause acute and chronic poison. Therefore, the study of analysis and detection methods for nitrogen oxides will be significant. There are many methods for the determination of nitrogen oxides such as ion chromatography [1], chemiluminescence [2,3], fluorescence [4], and colorimetric microdetermination [5]. However, the method that nitrogen oxides in the air were determined with Rhodamine B by fluorescence quenching has not been reported.

Nitrogen oxides can exist in various forms including the main forms of $\mathrm{NO}$ and $\mathrm{NO}_{2}$ in the atmosphere. In this research, the contents of $\mathrm{NO}$ and $\mathrm{NO}_{2}$ in the air sample were determined indirectly by measuring the content of nitrite and solution absorption-fluorescence spectrometry. There are many methods for the determination of nitrite such as spectrophotometry [6-8], fluorescence [9-14], chemiluminescence [15-17], polarography [18] and chromatography [19-22]. Among these methods, the fluorescence method has attracted much attention and been applied widely for the detection of nitrite for the high sensitivity, selectivity, low limit of detection and simple operation. According to the literature, $\mathrm{NO}_{2}^{-}$-organic dyes and $\mathrm{NO}_{2}^{-}-\mathrm{KBrO}_{3}^{-}$-organic dyes are the main systems for the determination of nitrite by the fluorescence spectrometry.

The common determination of nitrogen oxides is Saltzman method $[23,24]$. However, the contents of $\mathrm{NO}$ and $\mathrm{NO}_{2}$ in the actual air sample are determined with Rhodamine $B$ by fluorescence quenching with quite satisfactory results. The method in the text is simple and has a lower limit of detection, which provides a referee for the assessment of environment.

\section{Experimental Section}

2.1. Instruments and Reagents. An LS-55 fluorescence spectrophotometry instrument (PerkinElmer Limited) equipped with a $1 \mathrm{~cm} * 1 \mathrm{~cm}$ quartz cell, an HHS electrothermal thermostatic water-bath pot (Shanghai Boxun Co.), air sampler (Wuhan Tianhong TH-110B type), porous glass plate absorbs bottles packed with $10 \mathrm{~mL}$ absorbing liquid for short time sampling.

Nitrite working solution $(5.0 \mu \mathrm{g} / \mathrm{mL})$ was prepared by diluting the stock solution $(1.0 \mathrm{~g} / \mathrm{L})$ before use. Rhodamine B working solution $\left(5.0 \times 10^{-6} \mathrm{~mol} / \mathrm{L}\right)$, sulfuric acid solution, 


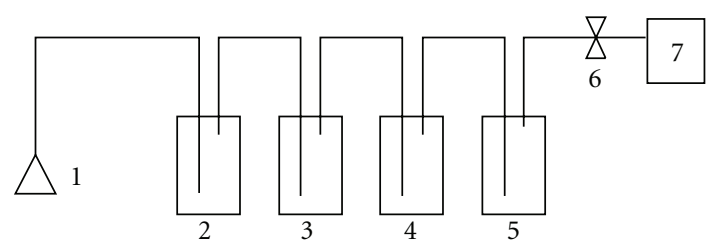

Figure 1: The scheme of air sampling device. (1) air inlet, (2) absorb bottle, (3) bottle of acidic potassium permanganate, (4) absorb bottle, (5) buffer bottle, (6) flowmeter, (7) Air sampler.

sodium acetate solution $(2.0 \mathrm{~mol} / \mathrm{L})$. Absorbing liquid was prepared as follows. $4 \mathrm{~mL}$ of sulfuric acid solution $(0.1 \mathrm{~mol} / \mathrm{L})$ and $12.00 \mathrm{~mL}$ of Rhodamine $\mathrm{B}$ solution was added into a $100 \mathrm{~mL}$ volumetric flask and diluted with the distilled water. Oxidation liquid $(0.16 \mathrm{~mol} / \mathrm{L})$ was prepared by dissolving $2.5286 \mathrm{~g}$ of potassium permanganate in $50 \mathrm{~mL}$ of water with slight fever, in which $50 \mathrm{~mL}$ of sulfuric acid solution $(1 \mathrm{~mol} / \mathrm{L}) 50 \mathrm{~mL}$ was added. The prepared solution was stored in brown reagent bottle. All chemicals were of analytical grade and used without further purification. All solutions were prepared with ultrapure water.

\subsection{Experimental Methods}

2.2.1. Air Sample Collection and Processing. Nitrogen oxides in the air were determined actually by measuring the contents of $\mathrm{NO}_{2}$ and $\mathrm{NO}$. $\mathrm{NO}_{2}$ can be absorbed directly by the absorption solution while NO cannot be adsorbed. Therefore, to determine the amount of nitrogen oxides, $\mathrm{NO}$ must be oxidized firstly to $\mathrm{NO}_{2}$. In our research, $\mathrm{NO}$ was oxidized by $10.0 \mathrm{~mL}$ of acidic potassium permanganate solution and the volume of absorption solution was $10.0 \mathrm{~mL}$. The scheme of air sampling device is shown in Figure 1.

The expression of concentration is given as follows:

$$
\begin{array}{r}
C_{\mathrm{NO}_{\mathrm{x}}}=C_{\mathrm{NO}_{2}}+C_{\mathrm{NO}}, \\
C_{\mathrm{NO}_{2}}=\frac{\left(\Delta F_{1}-a\right) \cdot V}{b \cdot f \cdot V_{0}}, \\
C_{\mathrm{NO}}=\frac{\left(\Delta F_{2}-a\right) \cdot V}{b \cdot f \cdot k \cdot V_{0}},
\end{array}
$$

where $C_{\mathrm{NO}_{\mathrm{x}}}$ : concentration of nitrogen oxides in the air, $\mathrm{mg} / \mathrm{m}^{3} ; \mathrm{C}_{\mathrm{NO}_{2}}$ : concentration of nitrogen dioxide in the air, $\mathrm{mg} / \mathrm{m}^{3} ; \mathrm{C}_{\mathrm{NO}}$ : concentration of nitric oxide in the air, $\mathrm{mg} / \mathrm{m}^{3}$; $\Delta F_{1}, \Delta F_{2}$ : difference between the value of fluorescent signal of the first and the second branch absorption in bottle sample and the value of blank signal, respectively; b, a: slope $(\Delta F \cdot \mathrm{mL} / \mu \mathrm{g})$ and intercept of linear regression equation of standard curve, respectively; $V$ : volume of the absorption solution, $\mathrm{mL} ; V_{0}$ : volume of the sample under standard state $(101.325 \mathrm{kPa}, 273 \mathrm{~K}), \mathrm{L} ; \mathrm{K}$ : oxidation coefficient of $\mathrm{NO} \rightarrow$ $\mathrm{NO}_{2}, 0.68$; and $F$ : coefficient of Saltzman experiment, 0.88 (it is 0.77 when the content of $\mathrm{NO}_{2}$ in the air is higher than $0.720 \mathrm{mg} / \mathrm{m}^{3}$ ).

2.2.2. Determination Method. $1.00 \mathrm{~mL}$ of $\mathrm{H}_{2} \mathrm{SO}_{4}$ solution $(0.1 \mathrm{~mol} / \mathrm{L}), 3.00 \mathrm{~mL}$ of Rhodamine $\mathrm{B}$ solution $(5.0 \times$

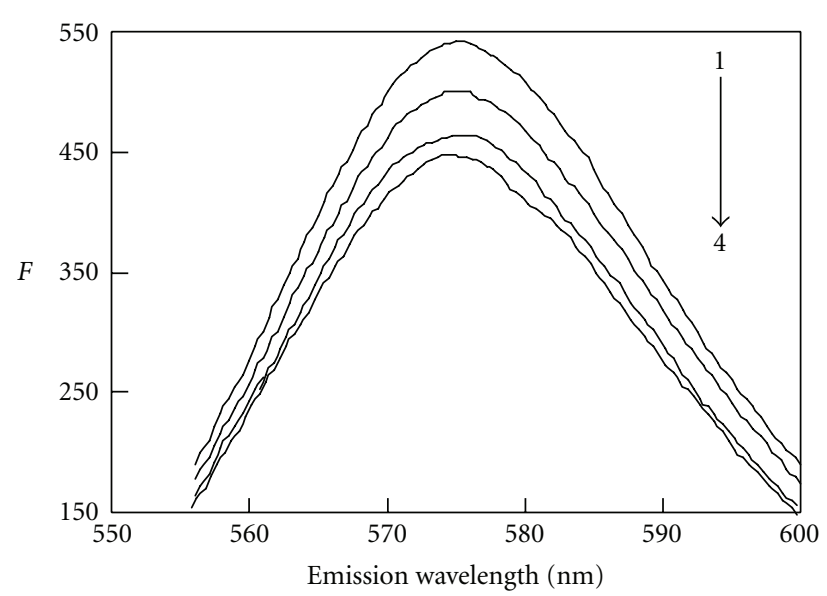

FIgURE 2: Fluorescence emission spectra. (1) Rhodamine B + $\mathrm{H}_{2} \mathrm{SO}_{4}+\mathrm{NaAc}$, (2) Rhodamine $\mathrm{B}+\mathrm{H}_{2} \mathrm{SO}_{4}$, (3) Rhodamine $\mathrm{B}$ $+\mathrm{H}_{2} \mathrm{SO}_{4}+\mathrm{NO}_{2}^{-}+\mathrm{NaAc}$, (4) Rhodamine $\mathrm{B}+\mathrm{H}_{2} \mathrm{SO}_{4}+\mathrm{NO}_{2}^{-}$. Rhodamine B: $6.0 \times 10^{-7} \mathrm{~mol} / \mathrm{L}, \mathrm{H}_{2} \mathrm{SO}_{4}: 4.0 \times 10^{-3} \mathrm{~mol} / \mathrm{L}, \mathrm{NO}_{2}^{-}$: $0.4 \mu \mathrm{g} / \mathrm{mL}$, NaAc: $0.08 \mathrm{~mol} / \mathrm{L}$, temperature: $60^{\circ} \mathrm{C}$, time: 45 minutes.

$10^{-6} \mathrm{~mol} / \mathrm{L}$ ), and a certain amount of nitrite standard solution were added in sequence into a $25 \mathrm{~mL}$ colorimetric tube, which was diluted with water to total volume of $25 \mathrm{~mL}$ and shaken before it was placed in a water bath $\left(60^{\circ} \mathrm{C}\right)$ for 45 minutes. Then, the colorimetric tube was taken out for cooling. $1.00 \mathrm{~mL}$ of sodium acetate solution $(2.0 \mathrm{~mol} / \mathrm{L})$ was added further into the above solution and shaken well. The excitation and emission wavelengths were $555 \mathrm{~nm}$ and $576 \mathrm{~nm}$, respectively. The fluorescence intensity of both sample solution $(F)$ and corresponding blank solution $\left(F_{0}\right)$ was detected. The value of $\Delta F\left(F_{0}-F\right)$ was recorded.

\section{Results and Discussion}

3.1. Excitation and Emission Spectrum. Rhodamine B is a kind of pinkish synthetic dye, which has intense fluorescence in solution and has been used commonly in fluorescent dye of cell, colored glass, and characteristic fireworks, and so forth. Figure 2 shows the fluorescence emission spectra of different Rhodamine B systems. It can be found that the fluorescent intensity of Rhodamine $\mathrm{B}$ decreases with the addition of $\mathrm{NO}_{2}^{-}$(curve 4 ) in the system of Rhodamine $\mathrm{B}$ $+\mathrm{H}_{2} \mathrm{SO}_{4}$ (curve 2). Curve 1 and 3 shows that the system can be activated when an appropriate amount of sodium acetate is added. In addition, there is a linear relationship between the concentration of $\mathrm{NO}_{2}^{-}$and $\Delta F$ under certain conditions. It can be concluded that a method for the determination of $\mathrm{NO}_{2}$ and $\mathrm{NO}$ is developed by fluorescence spectrophotometry. The maximum excitation and emission wavelengths for the system are $555 \mathrm{~nm}$ and $576 \mathrm{~nm}$, respectively.

3.2. Influence of Reaction Media. The influence of reaction media in $\Delta F$ was analyzed. Different acidic media was investigated, such as sulfuric acid, hydrochloric acid, acetic acid, phosphoric acid, and nitric acid. The highest sensitivity was detected in the sulfuric acid media. Therefore, sulfuric 
TABLE 1: Results of the determination of $\mathrm{NO}_{x}$ in the air samples.

\begin{tabular}{lcccc}
\hline Place of sample & $\begin{array}{c}\text { Average concentration of } \\
\mathrm{NO}_{x} \text { per hour }\left(\mathrm{mg} / \mathrm{m}^{3}\right)\end{array}$ & $\begin{array}{c}\mathrm{RSD}(\%) \\
(n=6)\end{array}$ & Saltzman method & $\begin{array}{c}\text { Method } \\
\text { recovery }(\%)\end{array}$ \\
\hline $\begin{array}{l}\text { Laboratory } \\
\begin{array}{l}\text { Outside of } \\
\text { laboratory }\end{array}\end{array}$ & 0.0297 & 3.4 & 0.0304 & 104.7 \\
$\begin{array}{l}\text { A gymnastical } \\
\text { zone }\end{array}$ & 0.0095 & 7.4 & 0.0086 & 97.8 \\
\hline
\end{tabular}

acid was used in this experiment. In addition, the effect of dosage of sulfuric acid $(0.1 \mathrm{~mol} / \mathrm{L})$ was also studied in the range of $0.2 \sim 2.00 \mathrm{~mL}$. It was found that the maximum value of $\Delta F$ could be obtained as the dosage was $1.00 \mathrm{~mL}$. Then, $1.00 \mathrm{~mL}$ of sulfuric acid solution was used in the experiment.

3.3. Influence of Dosage of Rhodamine B. The influence of Rhodamine B solution $\left(5.0 \times 10^{-6} \mathrm{~mol} / \mathrm{L}\right)$ in $\Delta F$ was also studied. Results indicated that fluorescent signal of the system increased gradually with the increased Rhodamine $\mathrm{B}$ dosage while the value of $\Delta F$ increased firstly and then decreased. The maximum value of $\Delta F$ was obtained when the dosage of Rhodamine B was $3.00 \mathrm{~mL}$. Therefore, $3.00 \mathrm{~mL}$ of Rhodamine B was chosen as optimum dosage in the further studies.

3.4. Influence of Dosage of Activator. Different materials were used to study the influence of activator, such as sodium citric acid, citric acid, sodium acetate, oxalic acid, sodium phosphoric acid and sodium dodecyl sulfonic acid. Both the improved fluorescence intensity and value of $\Delta F$ were detected by using the sodium acetate. Furthermore, the largest value of $\Delta F$ could be obtained for the $1.00 \mathrm{~mL}$ of sodium citrate solution $(2.0 \mathrm{~mol} / \mathrm{L})$. Hence, $1.00 \mathrm{~mL}$ of sodium citrate was chosen in the experiment.

3.5. Influence of Reaction Temperature. The influence of temperature on the value of $\Delta F$ was tested in the range of $25 \sim 80^{\circ} \mathrm{C}$. It was found that the value of $\Delta F$ increased gradually with the increased temperature. Moreover, the value of $\Delta F$ was relatively constant in the range of $60^{\circ} \mathrm{C}-80^{\circ} \mathrm{C}$. Then, the reaction temperature was performed at $60^{\circ} \mathrm{C}$ in the experiment.

3.6. Influence of Reaction Time. The variation of the value of $\Delta F$ was studied with the operation time. It was found that the value of $\Delta F$ increased fast with the prolonged reaction time in 40 minutes. The stable values of $\Delta F$ was observed with the further increased reaction time. The reaction time was chosen at 45 minutes in this experiment.

3.7. Stability Test. The fluorescence intensity was recorded after the reaction was terminated for 4 hours. The decreased fluorescence intensity was observed in 2 hours. However, the value of $\Delta F$ was unchanged, which indicated that this system was comparatively stable. Therefore, the determination could still be carried out in 2 hours.
3.8. Working Curve and Limit of Detection. Under the optimal conditions described above, a linear relationship between the concentration of $\mathrm{NO}_{2}^{-}$and the value of $\Delta F$ was obtained in the concentration range of $0.009 \sim 0.500 \mu \mathrm{g} / \mathrm{mL}$ of $\mathrm{NO}_{2}^{-}$. The linear regression equation is

$$
\Delta F=49.042 \rho(\mu \mathrm{g} / \mathrm{mL})-1.098 .
$$

The correlation coefficient $(r)$ was 0.9992 . The limit of detection was calculated to be $0.003 \mu \mathrm{g} / \mathrm{mL}$ by $3 \mathrm{Sb} / \mathrm{k}$ ( $\mathrm{Sb}$ the standard deviation of blank, and $\mathrm{k}$ the slope of linear calibration). The relative standard deviation $(n=10)$ was $3.23 \%$ for $0.25 \mu \mathrm{g} / \mathrm{mL} \mathrm{NO}_{2}^{-}$. The limit of detection of $\mathrm{NO}_{2}$ was $0.004 \mathrm{mg} / \mathrm{m}^{3}$ as $30 \mathrm{~L}$ solution was sampled by $10 \mathrm{~mL}$ of absorbing solution.

3.9. Influence of Coexistent Ion. In order to examine the effect of foreign ions in the air on the determination of nitrite, a number of ions were investigated according to the recommended procedure. The maximum error was restricted to be $\pm 5 \%$ for the $0.25 \mu \mathrm{g} / \mathrm{mL}$ nitrite. The limits of the tolerant foreign ions (by times) were $\mathrm{Cl}^{-}(10,000), \mathrm{CO}_{3}^{2-}$ and $\mathrm{SO}_{4}^{2-}(3000), \mathrm{PO}_{4}^{3-}(900), \mathrm{Br}^{-}(700), \mathrm{NH}_{4}^{+}$and $\mathrm{F}^{-}(600)$, Formaldehyde and $\mathrm{NO}^{3-}(500), \mathrm{I}^{-}$and $\mathrm{SO}_{3}^{2-}(110)$, and $\mathrm{Pb}^{2+}$ (21), respectively. It could be seen that most of ions, even in a large excess, did not interfere with the detection.

\section{Determination of Samples}

Gas samples were sampled with a speed of $0.2 \mathrm{~L} / \mathrm{min}$ for 2.5 hours. The content of targets can be calculated according to the fluorescent intensity of the absorbing liquid in two absorb bottles. The method has been applied to determine the concentration of $\mathrm{NO}_{x}$ in the atmosphere of a laboratory building and make the comparison with Saltzman method. The breakthrough point is that the limit of determination is lower than Saltzman method. The results are shown in Table 1.

\section{Conclusion}

In summary, this paper has established a new method of the concentration of $\mathrm{NO}_{2}$ and $\mathrm{NO}$ in the air detected by the fluorescence quenching method, determination results were lower than air quality standards stipulated in the standard $\left(0.24 \mathrm{mg} / \mathrm{m}^{3}\right)$. The method is simple and has a low limit of detection. It can be a referee for the environmental evaluation. 


\section{Acknowledgments}

The authors are thankful for the help from Song $\mathrm{Hu}$ Yao for the discussion, and the members in our lab are acknowledged.

\section{References}

[1] Y. Komazaki, H. Shimizu, and S. Tanaka, "A new measurement method for nitrogen oxides in the air using an annular diffusion scrubber coated with titanium dioxide," Atmospheric Environment, vol. 33, no. 27, pp. 4363-4371, 1999.

[2] M. J. Navas, A. M. Jiménez, and G. Galán, "Air analysis: determination of nitrogen compounds by chemiluminescence," Atmospheric Environment, vol. 31, no. 21, pp. 3603-3608, 1997.

[3] Y. Wang, S. H. Fan, and S. L. Wang, "Chemiluminescence determination of nitrogen oxide in air with a sequential injection method," Analytica Chimica Acta, vol. 541, no. 1-2, pp. 131-136, 2005.

[4] X. Q. Zhan, D. H. Li, H. Zheng, J. G. Xu, and Y. Q. Zhou, "Fluorimetric determination of nitrogen oxides in the air by a novel red-region fluorescent reagent," Talanta, vol. 58, no. 5, pp. 855-860, 2002.

[5] B. E. Saltzman, "Colorimetric microdetermination of nitrogen dioxide in the atmosphere," Analytical Chemistry, vol. 26, no. 12, pp. 1949-1955, 1954.

[6] H. Weiping and D. Xuezhi, "Determination of trace nitrite by catalytic spectrophotometric method with methyl violet," Analytical Laboratory, vol. 16, no. 1, pp. 59-62, 2005.

[7] K. Jichuan, M. Juan, Y. Hong et al., "Spectrophotometry determination of trace nitrite in food products," Chinese Journal of Spectroscopy Laboratory, vol. 26, no. 3, pp. 541-543, 2009.

[8] C. Xing-Chen, "Determination of trace nitrite by catalytic spectrophotometry with basic fuchsin," Chinese Journal of Spectroscopy Laboratory, vol. 26, no. 3, pp. 724-726, 2009.

[9] F. Suling, T. Anna, and F. Jing, "Determination of nitrite by fluorimetric method," Analytical Labrotory, vol. 2, pp. 41-43, 2001.

[10] R. Huiujan and Y. Liping, "Fluorophotometric determination of nitrite with tyrosine," Analytical Laboratory, vol. 22, no. 1, pp. 90-91, 2003.

[11] K. Jichuan, N. Jianping, Z. Na et al., "A fluorescence quenching method for determination of trace nitrite," Analytical Laboratory, vol. 24, no. 7, pp. 7-9, 2005.

[12] N. Jie, J. Yang, and F. Meng, "Fluorimetric determination of nitrite," Talanta, vol. 40, no. 7, pp. 1009-1011, 1993.

[13] L. Jingguo, W. Yaorong, and T. Yalian, "Determination of trace nitrite based on fluorescence quenching with I-Rhodamine B system," Chinese Journal of Analytical Chemistry, vol. 25, no. 5, pp. 590-593, 1997.

[14] X. Zhang, H. Wang, N. N. Fu, and H. S. Zhang, "A fluorescence quenching method for the determination of nitrite with Rhodamine 110," Spectrochimica Acta A, vol. 59, no. 8, pp. 1667-1672, 2003.

[15] W. Wane, D. Yong, W. Tiansheng et al., "Determination of $\mathrm{NO}_{2}^{-}$in air by chemiluminescence detection," Environmental Science and Technology, vol. 32, no. 10, pp. 133-136, 2009.

[16] W. Wane, W. Tiansheng, and Z. Zeyang, "Determination of trace nitrite in water using potassium bromate-acid chrome blue $\mathrm{K}$ chemiluminescent method," Journal of Analytical Science, vol. 24, no. 3, pp. 327-330, 2008.
[17] M. Glasius, M. F. Carlsen, T. S. Hansen, and C. Lohse, "Measurements of nitrogen dioxide on Funen using diffusion tubes," Atmospheric Environment, vol. 33, no. 8, pp. 11771185, 1999.

[18] Z. Gao, G. Wang, and Z. Zhao, "Determination of trace amounts of nitrite by single-sweep polarography," Analytica Chimica Acta, vol. 230, no. 1, pp. 105-112, 1990.

[19] W. S. Jobgen, S. C. Jobgen, H. Li, C. J. Meininger, and G. $\mathrm{Wu}$, "Analysis of nitrite and nitrate in biological samples using high-performance liquid chromatography," Journal of Chromatography B, vol. 851, no. 1-2, pp. 71-82, 2007.

[20] N. Lohumi, S. Gosain, A. Jain, V. K. Gupta, and K. K. Verma, "Determination of nitrate in environmental water samples by conversion into nitrophenols and solid phase extraction-spectrophotometry, liquid chromatography or gas chromatography-mass spectrometry," Analytica Chimica Acta, vol. 505, no. 2, pp. 231-237, 2004.

[21] I. Sarudi and I. Nagy, "A gas chromatographic method for the determination of nitrite ions in natural waters," Talanta, vol. 42, no. 8, pp. 1099-1102, 1995.

[22] Y. Miura and H. Hamada, "Ion chromatography of nitrite at the ppb level with photometric measurement of iodine formed by post-column reaction of nitrite with iodide," Journal of Chromatography A, vol. 850, no. 1-2, pp. 153-160, 1999.

[23] B. E. Saltzman, "Colorimetric microdetermination of nitrogen dioxide in the atmosphere," Analytical Chemistry, vol. 26, no. 12, pp. 1949-1955, 1954.

[24] Y. Y. Zhou, S. K. She, Q. Lu, C. Q. Zhu, and L. Wang, "Highly sensitive spectrofluorimetric determination of trace amounts of nitrite with N-(1-naphthyl) ethylenediamine," Spectroscopy and Spectral Analysis, vol. 25, no. 8, pp. 1318-1321, 2005. 


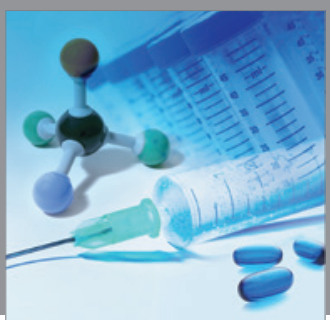

International Journal of

Medicinal Chemistry

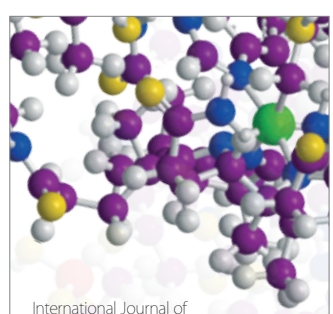

Carbohydrate Chemistry

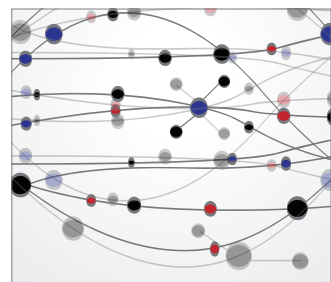

The Scientific World Journal
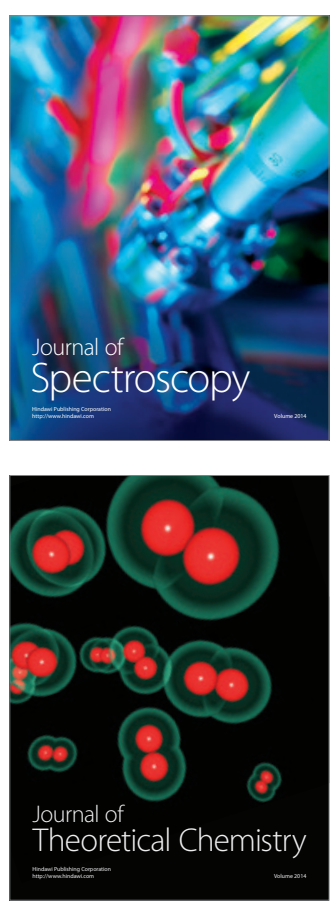
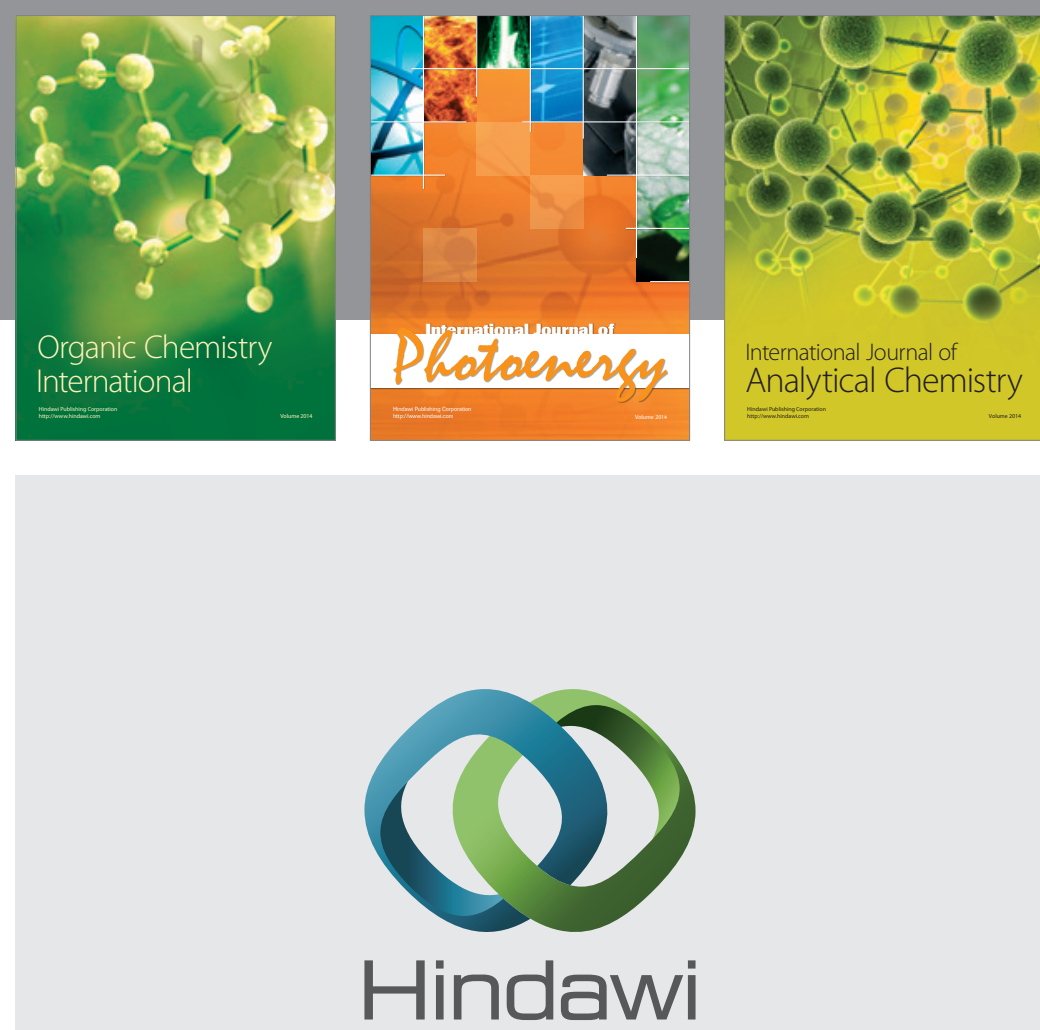

Submit your manuscripts at

http://www.hindawi.com
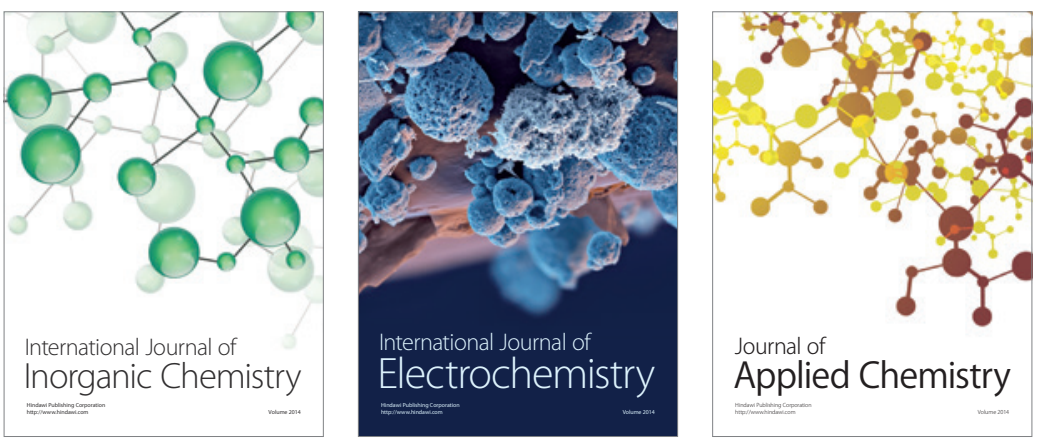

Journal of

Applied Chemistry
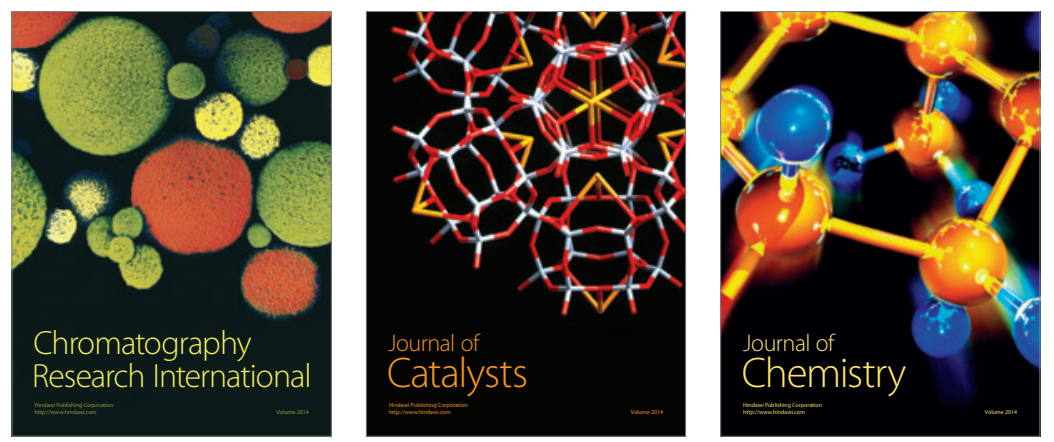
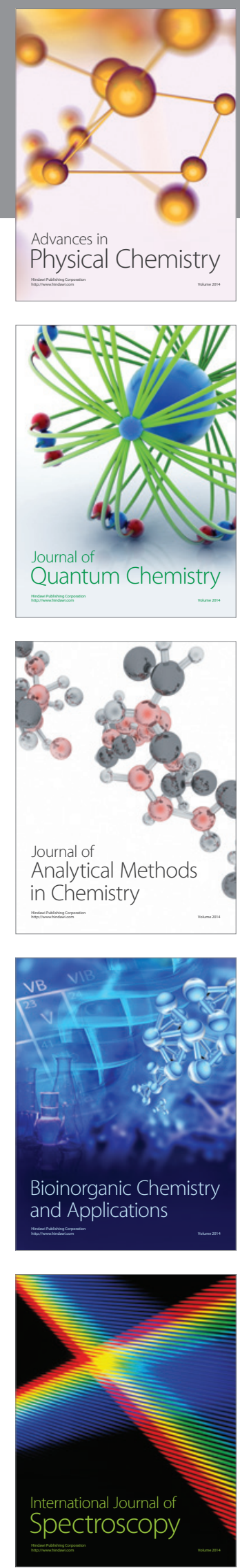